\title{
Sporosarcina antarctica sp. nov., a psychrophilic bacterium isolated from the Antarctic
}

\author{
Yong Yu, ${ }^{1}$ Yu-Hua Xin, ${ }^{2}$ Hong-Can Liu, ${ }^{2}$ Bo Chen, ${ }^{1}$ Jun Sheng, ${ }^{3}$ \\ Zhen-Ming Chi, ${ }^{3}$ Pei-Jin Zhou ${ }^{2}$ and De-Chao Zhang ${ }^{3}$ \\ ${ }^{1}$ SOA Key Laboratory for Polar Science, Polar Research Institute of China, Shanghai 200136, \\ PR China \\ ${ }^{2}$ China General Microbiological Culture Collection Center and State Key Laboratory of Microbial \\ Resources, Institute of Microbiology, Chinese Academy of Sciences, Beijing 100101, PR China \\ ${ }^{3}$ UNESCO Chinese Center of Marine Biotechnology, Ocean University of China, Qingdao 266003, \\ PR China
}

Correspondence

De-Chao Zhang

zhangdechao@yahoo.cn

\begin{abstract}
A Gram-positive, psychrophilic, rod-shaped bacterium, designated strain $\mathrm{N}-05^{\top}$, was isolated from soil samples collected off King George Island, west Antarctica (62 $13^{\prime} 3^{\prime \prime} \mathrm{S} 58^{\circ} 57^{\prime} 08^{\prime \prime}$ W). Phylogenetic analysis based on 16S rRNA gene sequences showed that strain $\mathrm{N}-05^{\top}$ was related to members of the genus Sporosarcina and had highest 16S rRNA gene sequence similarity with the type strain of Sporosarcina macmurdoensis (98.0\%). The temperature range for growth of strain $\mathrm{N}-05^{\top}$ was $0-23^{\circ} \mathrm{C}$, with optimum growth occurring at $17-18{ }^{\circ} \mathrm{C}$ and approximately $\mathrm{pH}$ 6.0-8.0. Strain $\mathrm{N}-05^{\top}$ had $\mathrm{MK}-7$ as the major menaquinone and anteiso- $\mathrm{C}_{15: 0}$ and $\mathrm{C}_{16: 1} \omega 7 \mathrm{c}$ alcohol as major fatty acids. The genomic DNA G+C content was $39.2 \mathrm{~mol} \%$. On the basis of phenotypic characteristics, phylogenetic analysis and DNA-DNA relatedness data, strain $\mathrm{N}-05^{\top}$ is considered to represent a novel species of the genus Sporosarcina, for which the name Sporosarcina antarctica is proposed. The type strain is $\mathrm{N}-05^{\top}\left(=\mathrm{CGMCC}_{1.6503^{\top}}=\mathrm{JCM}\right.$ $\left.14646^{\mathrm{T}}\right)$.
\end{abstract}

The genus Sporosarcina, which belongs to the family Bacillaceae, was proposed by Kluyver \& van Niel (1936) to accommodate bacteria that have spherical or oval-shaped cells and contain MK-7 as the major menaquinone. At the time of writing, the genus Sporosarcina comprises nine recognized species, namely Sporosarcina ureae (Claus et al., 1983; Claus \& Fahmy, 1986), S. globispora (Larkin \& Stokes, 1967; Yoon et al., 2001), S. psychrophila (Nakamura, 1984; Yoon et al., 2001), S. pasteurii (Chester, 1898; Yoon et al., 2001), S. aquimarina (Yoon et al., 2001), S. macmurdoensis (Reddy et al., 2003), S. koreensis and S. soli (Kwon et al., 2007), and S. saromensis (An et al., 2007). Here we report on the characterization of a novel psychrophilic bacterium of the genus Sporosarcina isolated from soil samples collected off King George Island, west Antarctica (62 $13^{\prime} 31^{\prime \prime} \mathrm{S} 58^{\circ} 57^{\prime}$ $08^{\prime \prime} \mathrm{W}$ ).

In the laboratory, frozen soil collected off King George Island was suspended in an equal volume of liquid PYG medium $(0.5 \%$ bacto peptone, $0.02 \%$ yeast extract, $0.5 \%$

The GenBank/EMBL/DDBJ accession number for the $16 \mathrm{~S}$ rRNA gene sequence of strain $\mathrm{N}-05^{\top}$ is $\mathrm{EF} 154512$.

A table detailing the cellular fatty acid content of strain $\mathrm{N}-05^{\top}$ in comparison with other recognized Sporosarcina species is available as supplementary material with the online version of this paper. glucose, $0.3 \%$ beef extract, $0.05 \% \mathrm{NaCl}$ and $0.15 \%$ $\mathrm{MgSO}_{4} \cdot 7 \mathrm{H}_{2} \mathrm{O}, \mathrm{w} / \mathrm{v}, \mathrm{pH}$ adjusted to 7.0 ; Zhang et al., 2007) supplemented with cycloheximide, nystatin and nalidixic acid (all at $25 \mu \mathrm{g} \mathrm{ml}^{-1}$ ) and shaken at $10{ }^{\circ} \mathrm{C}$ for 4 days at 150 r.p.m. The culture was further diluted $(1: 10)$ and spread onto PYG agar plates and incubated at $4{ }^{\circ} \mathrm{C}$ for 2 weeks. Strain $\mathrm{N}-05^{\mathrm{T}}$ was obtained in pure culture after three successive transfers to fresh PYG agar and stored at $-80{ }^{\circ} \mathrm{C}$ in $30 \%(\mathrm{v} / \mathrm{v})$ glycerol. S. macmurdoensis DSM $15428^{\mathrm{T}}$ was obtained from the DSMZ and routinely grown on $\mathrm{ABM}$ agar $(0.5 \%$ peptone, $0.2 \%$ yeast extract and $1.5 \%$ agar, w/v, pH 7.2) at $18{ }^{\circ} \mathrm{C}$ and used as a reference strain.

DNA was extracted and purified as described by Sambrook et al. (1989). The gene encoding $16 \mathrm{~S}$ rRNA was amplified by PCR with two universal primers (Zhang et al., 2007). Sequencing reactions were carried out by using an $\mathrm{ABI}$ BigDye 3.1 sequencing kit (Applied Biosystems) and an automated DNA sequencer (model ABI3730; Applied Biosystems). The nearly complete $16 \mathrm{~S}$ rRNA gene sequence (1446 bp) of strain $\mathrm{N}-05^{\mathrm{T}}$ was submitted to GenBank and EMBL to search for similar sequences by using the BLAST algorithm. A phylogenetic tree was constructed by using Kimura's two-parameter and pairwise-deletion model analysis implemented in the program MEGA version 3.0 (Kumar et al., 2004). Resultant tree topologies were 
evaluated by bootstrap analysis based on 1000 replicates. Phylogenetic analysis (Fig. 1) showed that strain $\mathrm{N}-05^{\mathrm{T}}$ was grouped with members of the genus Sporosarcina, and formed a distinct cluster with $S$. macmurdoensis DSM $15428^{\mathrm{T}} \quad(98.0 \%$ 16S rRNA gene sequence similarity) supported by a high bootstrap value $(100 \%)$ in the neighbour-joining tree. Levels of $16 \mathrm{~S}$ rRNA gene sequence similarity between strain $\mathrm{N}-05^{\mathrm{T}}$ and other strains used in the phylogenetic analysis were less than $95.6 \%$. A similar topology was found in the tree generated with the maximum-parsimony algorithm (data not shown).

Cell morphology of strain $\mathrm{N}-05^{\mathrm{T}}$ was examined with an Axioplan 2 microscope. Colony morphology was observed following incubation on PYG at $17{ }^{\circ} \mathrm{C}$. Growth temperature was determined with a TN3F temperature-gradient incubator (Advantec). The $\mathrm{pH}$ range for growth was determined by using PYG broth at various $\mathrm{pH}$ values adjusted with $\mathrm{HCl}$ or $\mathrm{NaOH}$ (both at $1 \mathrm{~mol} \mathrm{l}^{-1}$ ). Anaerobic growth was investigated in PYG medium in an anaerobic test tube filled with nitrogen gas. General physiological tests were performed by using conventional methods (Dong \& Cai, 2001). Acid production from carbohydrates was determined as described by Leifson (1963). API strips (API 20 E, API 20 NE, API ZYM; bioMérieux) were used to determine the physiological and biochemical characteristics of strain $\mathrm{N}-05^{\mathrm{T}}$ according to the manufacturer's instructions. The API strips were incubated for 4 days at $17{ }^{\circ} \mathrm{C}$. All of the tests were performed in duplicate. Morphological, physiological and biochemical characteristics of strain $\mathrm{N}-05^{\mathrm{T}}$ are given in the species description below or are shown in Table 1 .

Respiratory quinones were extracted and purified according to Collins (1985) and were analysed by HPLC (Wu et al., 1989) by using menaquinone 7 (MK-7) from S. macmur- doensis DSM $15428^{\mathrm{T}}$ as a reference. Cell-wall peptidoglycan was prepared and analysed in accordance with the methods of Komagata \& Suzuki (1987) and Zhang et al. (2007). For analysis of fatty acid methyl esters, cell mass of strain $\mathrm{N}-05^{\mathrm{T}}$ was harvested from PYG plates after incubation at $17{ }^{\circ} \mathrm{C}$ for 4 days. The fatty acid methyl esters were extracted and prepared according to the standard protocol of the MIDI (Microbial Identification) system (Sasser, 1990). Strain N$05^{\mathrm{T}}$ contained MK-7 as the major menaquinone. The peptidoglycan of the isolate contained a cell-wall type of LLys-D-Glu (variation A4 $\alpha$ ). The predominant cellular fatty acids of strain $\mathrm{N}-05^{\mathrm{T}}$ were anteiso- $\mathrm{C}_{15: 0}(39.75 \%$ of the total), $\mathrm{C}_{16: 1} \omega 7 c$ alcohol (18.89\%), iso- $\mathrm{C}_{17: 1} \mathrm{I}$ and/or anteiso- $\mathrm{C}_{17: 1} \mathrm{~B}(11.91 \%)$, iso- $\mathrm{C}_{14: 0}(7.55 \%)$, iso- $\mathrm{C}_{16: 0}$ $(7.01 \%)$, anteiso- $\mathrm{C}_{17: 0}(4.23 \%), \mathrm{C}_{16: 1} \omega 11 c(3.67 \%)$, iso$\mathrm{C}_{15: 0}(1.36 \%)$, iso- $\mathrm{C}_{16: 1}(1.30 \%)$ and $\mathrm{C}_{16: 0}(1.19 \%)$. The fatty acid profile of strain $\mathrm{N}-05^{\mathrm{T}}$ was similar to those of recognized Sporosarcina species (Yoon et al., 2001), although strain $\mathrm{N}-05^{\mathrm{T}}$ contained a greater proportion of unsaturated fatty acids $\left(\mathrm{C}_{16: 1} \omega 7 c\right.$ alcohol, iso- $\mathrm{C}_{17: 1} \mathrm{I}$ and/or anteiso$\mathrm{C}_{17: 1} \mathrm{~B}$ ), which contribute to the maintenance of membrane fluidity at low temperature. The fatty acid profiles of strain $\mathrm{N}-05^{\mathrm{T}}$ and other recognized Sporosarcina species are detailed in Supplementary Table S1 available in IJSEM Online.

The DNA G $+\mathrm{C}$ content was determined by using the thermal denaturation method with Escherichia coli K-12 as reference, and DNA-DNA hybridization experiments were performed using the liquid renaturation method (De Ley et al., 1970) as modified by Huß et al. (1983); both experiments were carried out by using a DU800 spectrophotometer (Beckman) with a thermal controller. The DNA G + C content of strain $\mathrm{N}-05^{\mathrm{T}}$ was $39.2 \mathrm{~mol} \%$. The level of DNA-DNA relatedness between strain $\mathrm{N}-05^{\mathrm{T}}$ and S. macmurdoensis DSM $15428^{\mathrm{T}}$ was as low as $41.7 \%$, much

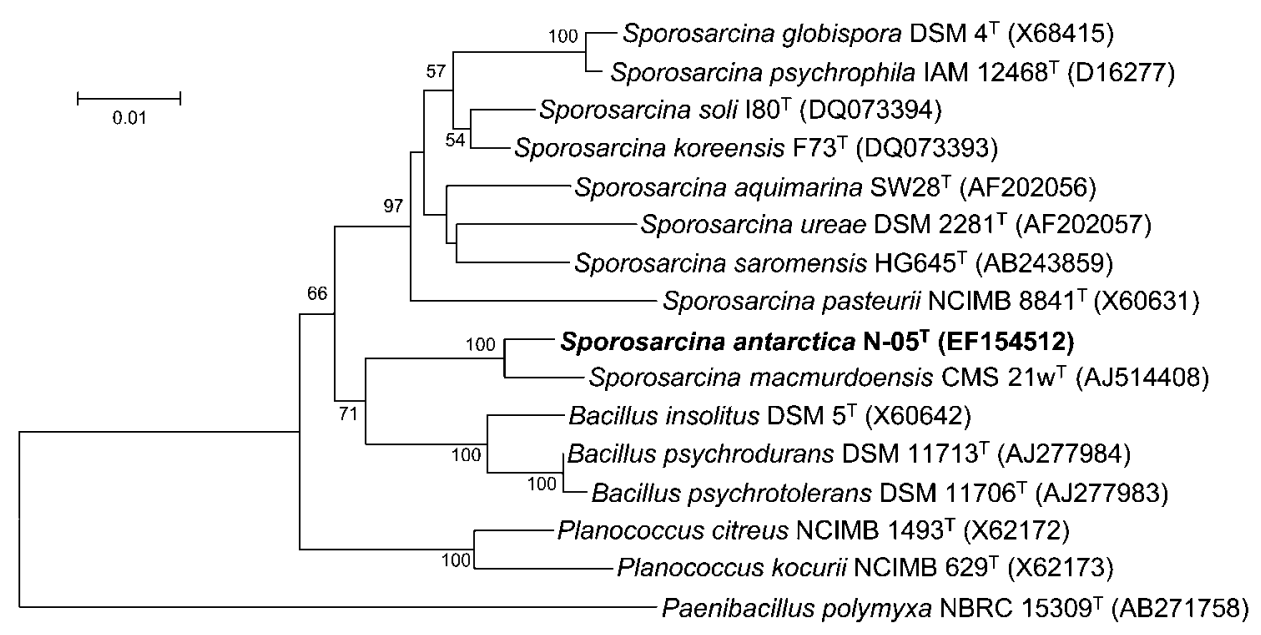

Fig. 1. Phylogenetic relationships between strain $\mathrm{N}-05^{\top}$, recognized members of the genus Sporosarcina and other related species based on 16S rRNA gene sequences. The tree was constructed by using the neighbour-joining method. Numbers at nodes represent levels of bootstrap support (\%) based on a neighbour-joining analysis of 1000 resampled datasets. GenBank accession numbers are given in parentheses. Bar, $1 \%$ sequence divergence. 
Table 1. Differential phenotypic characteristics between strain $\mathrm{N}-05^{\top}$ and recognized Sporosarcina species

Strains: $1, \mathrm{~N}-05^{\mathrm{T}}$ (S. antarctica sp. nov.); 2, S. macmurdoensis CMS $21 \mathrm{w}^{\mathrm{T}}$ (data from Reddy et al., 2003); 3, S. aquimarina SW28 ${ }^{\mathrm{T}}$ (Yoon et al., 2001);

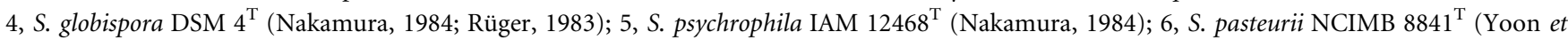
al., 2001); 7, S. ureae DSM $2281^{\mathrm{T}}$ (Claus \& Fahmy, 1986); 8, S. koreensis $\mathrm{F}_{3}{ }^{\mathrm{T}}$ (Kwon et al., 2007); 9, S. soli $\mathrm{I}^{\mathrm{T}}{ }^{\mathrm{T}}$ (Kwon et al., 2007); 10, S. saromensis HG645 ${ }^{\mathrm{T}}$ (An et al., 2007). +, Positive; -, negative; w, weak; NA, no data available.

\begin{tabular}{|c|c|c|c|c|c|c|c|c|c|c|}
\hline Characteristic & 1 & 2 & 3 & 4 & 5 & 6 & 7 & 8 & 9 & 10 \\
\hline Colony colour ${ }^{\star}$ & LY & WH & $\mathrm{LO}$ & WH & WH & WH & WH & LO & LO & $\mathrm{BE}$ \\
\hline Cell shape $\dagger$ & $\mathrm{R}$ & $\mathrm{R}$ & $\mathrm{R}$ & $\mathrm{R}$ & $\mathrm{R}$ & $\mathrm{S}$ & S & $\mathrm{R}$ & $\mathrm{R}$ & $\mathrm{R}$ \\
\hline Motility & - & - & + & + & + & + & + & + & - & + \\
\hline \multicolumn{11}{|l|}{ Growth at: } \\
\hline $5{ }^{\circ} \mathrm{C}$ & + & + & + & + & + & NA & NA & - & - & + \\
\hline $30{ }^{\circ} \mathrm{C}$ & - & - & + & + & $\mathrm{W}$ & + & + & + & + & + \\
\hline Anaerobic growth & + & + & + & + & - & + & - & - & - & - \\
\hline \multicolumn{11}{|l|}{ Presence of: } \\
\hline Oxidase & + & - & + & + & + & NA & + & + & + & + \\
\hline Urease & - & - & + & + & + & + & + & + & + & + \\
\hline $\mathrm{NaCl}$ tolerance $(\%)$ & 9 & 3 & 13 & 5 & 2 & 10 & 3 & 7 & 5 & 9 \\
\hline \multicolumn{11}{|l|}{ Hydrolysis of: } \\
\hline Casein & - & NA & - & - & $\mathrm{W}$ & $\mathrm{w}$ & - & - & - & - \\
\hline Gelatin & - & + & + & + & + & + & - & + & - & + \\
\hline Starch & - & + & - & - & $\mathrm{w}$ & - & - & - & - & + \\
\hline Nitrate reduction & - & - & + & + & - & + & + & - & + & - \\
\hline \multicolumn{11}{|l|}{ Acid production from: } \\
\hline D-Glucose & - & - & - & + & + & NA & NA & - & - & - \\
\hline D-Xylose & - & - & - & - & + & NA & NA & - & - & - \\
\hline D-Fructose & - & - & + & - & + & NA & NA & $\mathrm{NA}$ & $\mathrm{NA}$ & - \\
\hline D-Galactose & - & - & - & - & + & NA & NA & NA & NA & - \\
\hline D-Mannitol & - & - & - & - & + & $\mathrm{NA}$ & $\mathrm{NA}$ & - & - & - \\
\hline $\begin{array}{l}\text { DNA G }+ \text { C content } \\
(\mathrm{mol} \%)\end{array}$ & 39.2 & 44 & 40 & 40 & 44.1 & 39 & $40-42$ & 46.5 & 44.5 & 46 \\
\hline
\end{tabular}

${ }^{\star} \mathrm{BE}$, Beige; LO, light orange; LY, light yellow; WH, white.

$\dagger R$, Rods; S, spherical.

lower than the threshold (70\%) recommended for species demarcation (Wayne et al., 1987), thus verifying that strain $\mathrm{N}-05^{\mathrm{T}}$ represents a species distinct from $S$. macmurdoensis. 16S rRNA gene sequence similarities of less than $97.0 \%$ were found between strain $\mathrm{N}-05^{\mathrm{T}}$ and the type strains of other recognized species of the genus Sporosarcina. It has been suggested that in bacterial strains showing less than $97 \% 16 \mathrm{~S}$ rRNA gene sequence similarity, levels of DNADNA hybridization are less than $70 \%$ (Stackebrandt \& Goebel, 1994). Therefore, strain $\mathrm{N}-05^{\mathrm{T}}$ is genotypically distinct from all recognized species of the genus Sporosarcina.

Based on the phenotypic, phylogenetic and genomic evidence presented, strain $\mathrm{N}-05^{\mathrm{T}}$ is considered to represent a novel species of the genus Sporosarcina, for which the name Sporosarcina antarctica sp. nov. is proposed.

\section{Description of Sporosarcina antarctica sp. nov.}

Sporosarcina antarctica (ant.arc'ti.ca. L. fem. adj. antarctica southern, of the Antarctic, the geographical origin of the type strain).
Cells are Gram-positive, psychrophilic, non-motile rods, $0.3-0.6 \mu \mathrm{m}$ by $1.1-2.6 \mu \mathrm{m}$ in size. Colonies are light yellow, smooth, circular and convex with entire margins. Produces catalase and cytochrome oxidase. Growth occurs under anaerobic conditions on PYG medium. Growth occurs at $0-23{ }^{\circ} \mathrm{C}$ and $\mathrm{pH} 5.0-10.0$, with optimum growth at $17-$ $18{ }^{\circ} \mathrm{C}$ and approximately $\mathrm{pH} 6.0-8.0$. Growth occurs in the presence of $0-9 \%(\mathrm{w} / \mathrm{v}) \mathrm{NaCl}$. Nitrate is not reduced and hydrogen sulfide is not produced. Negative for indole production and the Voges-Proskauer recation. Negative for arginine dihydrolase, lysine decarboxylase, ornithine decarboxylase, leucine arylamidase, valine arylamidase, cystine arylamidase, urease, gelatinase, caseinase, trypsin, amylase, lecithinase, acid phosphatase, esterase (C4), esterase lipase (C8), lipase (C14), $\alpha$-galactosidase, $\beta$ galactosidase, $\beta$-glucuronidase, $\alpha$-glucosidase, $\beta$-glucosidase, $N$-acetyl- $\beta$-glucosaminidase, $\alpha$-mannosidase, $\alpha$-fucosidase and $\alpha$-chymotrypsin. Positive for naphthol-AS-BIphosphohydrolase and alkaline phosphatase. D-Glucose and $\alpha$-ketobutyric acid can be utilized as sole carbon sources, but not sucrose, lactose, galactose, trehalose, cellobiose, L-rhamnose, melibiose, raffinose, D-sorbitol, 
inositol, maltose, glucose, glycerol, fructose, melezitose, Larabinose, D-mannose, mannitol, $\mathrm{N}$-acetylglucosamine, malate, succinate, capric acid, adipic acid or phenylacetic acid. Acid is not produced from the following carbohydrates: D-glucose, fructose, sucrose, lactose, galactose, trehalose, cellobiose, L-rhamnose, melibiose, raffinose, Dsorbitol, inositol, maltose, glycerol, melezitose, L-arabinose, D-mannose or mannitol. MK-7 is the major menaquinone. The cell wall contains peptidoglycans of the L-Lys-D-Glu type (variation $\mathrm{A} 4 \alpha$ ). Predominant cellular fatty acids are anteiso- $\mathrm{C}_{15: 0}\left(39.75 \%\right.$ of the total), $\mathrm{C}_{16: 1} \omega 7 c$ alcohol $(18.89 \%)$, iso- $\mathrm{C}_{17: 1} \mathrm{I}$ and/or anteiso- $\mathrm{C}_{17: 1} \mathrm{~B}(11.91 \%)$, iso- $\mathrm{C}_{14: 0} \quad(7.55 \%)$, iso- $\mathrm{C}_{16: 0} \quad(7.01 \%)$, anteiso- $\mathrm{C}_{17: 0}$ $(4.23 \%)$ and $\mathrm{C}_{16: 1} \omega 11 c(3.67 \%)$. The DNA G + C content of the type strain is $39.2 \mathrm{~mol} \%$.

The type strain, $\mathrm{N}-05^{\mathrm{T}}\left(=\mathrm{CGMCC} 1.6503^{\mathrm{T}}=\mathrm{JCM} 14646^{\mathrm{T}}\right)$, was isolated from soil samples collected off King George Island, west Antarctica ( $\left.62^{\circ} 13^{\prime} 31^{\prime \prime} \mathrm{S} 58^{\circ} 57^{\prime} 08^{\prime \prime} \mathrm{W}\right)$.

\section{Acknowledgements}

This work was supported by the National Natural Science Foundation of China (30500001), the National Basic Research Program of China (2004CB719601) and the National Infrastructure of Natural Resources for Science and Technology Program of China (No. 2005DKA21209).

\section{References}

An, S.-Y., Haga, T., Kasai, H., Goto, K. \& Yokota, A. (2007). Sporosarcina saromensis sp. nov., an aerobic endospore-forming bacterium. Int J Syst Evol Microbiol 57, 1868-1871.

Chester, F. D. (1898). Report of the mycologist: bacteriological work. Del Agric Exp Stn Annu Rep 10, 47-137.

Claus, D. \& Fahmy, F. (1986). Genus Sporosarcina Kluyver and van Niel 1936, 401 ${ }^{\mathrm{AL}}$. In Bergey's Manual of Systematic Bacteriology, vol. 2, pp. 1202-1206. Edited by P. H. A. Sneath, N. S. Mair, M. E. Sharpe \& J. G. Holt. Baltimore: Williams \& Wilkins.

Claus, D., Fahmy, F., Rolf, H. J. \& Tosunoglu, N. (1983). Sporosarcina halophila sp. nov., an obligate, slightly halophilic bacterium from salt marsh soils. Syst Appl Microbiol 4, 496-506.

Collins, M. D. (1985). Isoprenoid quinone analysis in classification and identification. In Chemical Methods in Bacterial Systematics, pp. 267-287. Edited by M. Goodfellow \& D. E. Minnikin. London: Academic Press.

De Ley, J., Cattoir, H. \& Reynaerts, A. (1970). The quantitative measurement of DNA hybridization from renaturation rates. Eur $J$ Biochem 12, 133-142.

Dong, X.-Z. \& Cai, M.-Y. (editors) (2001). Determination of biochemical properties. In Manual for the Systematic Identification of General Bacteria, pp. 370-398. Beijing: Science Press (in Chinese).

Huß, V. A. R., Festl, H. \& Schleifer, K.-H. (1983). Studies on the spectrophotometric determination of DNA hybridization from renaturation rates. Syst Appl Microbiol 4, 184-192.
Kluyver, A. J. \& van Niel, C. B. (1936). Prospects for a natural classification of bacteria. Zentralbl Bakteriol Parasitenkd Infektionskr Hyg Abt II 94, 369-403.

Komagata, K. \& Suzuki, K. (1987). Lipid and cell-wall analysis in bacterial systematics. Methods Microbiol 19, 161-207.

Kumar, S., Tamura, K. \& Nei, M. (2004). MEGA3: Integrated software for Molecular Evolutionary Genetics Analysis and sequence alignment. Brief Bioinform 5, 150-163.

Kwon, S.-W., Kim, B.-Y., Song, J., Weon, H.-Y., Schumann, P., Tindall, B. J., Stackebrandt, E. \& Fritze, D. (2007). Sporosarcina koreensis sp. nov. and Sporosarcina soli sp. nov., isolated from soil in Korea. Int $J$ Syst Evol Microbiol 57, 1694-1698.

Larkin, J. M. \& Stokes, J. L. (1967). Taxonomy of psychrophilic strains of Bacillus. J Bacteriol 94, 889-895.

Leifson, E. (1963). Determination of carbohydrate metabolism of marine bacteria. J Bacteriol 85, 1183-1184.

Nakamura, L. K. (1984). Bacillus psychrophilus sp. nov., nom. rev. Int J Syst Bacteriol 34, 121-123.

Reddy, G. S. N., Matsumoto, G. I. \& Shivaji, S. (2003). Sporosarcina macmurdoensis sp. nov., from a cyanobacterial mat sample from a pond in the McMurdo Dry Valleys, Antarctica. Int J Syst Evol Microbiol 53, 1363-1367.

Rüger, H.-J. (1983). Differentiation of Bacillus globisporus, Bacillus marinus comb. nov., Bacillus aminovorans, and Bacillus insolitus. Int J Syst Bacteriol 33, 157-161.

Sambrook, J., Frisch, E. F. \& Maniatis, T. (1989). Molecular Cloning: a Laboratory Manual, 2nd edn. Cold Spring Harbor, NY: Cold Spring Harbor Laboratory Press.

Sasser, M. (1990). Identification of bacteria by gas chromatography of cellular fatty acids, MIDI Technical Note 101. Newark, DE: MIDI Inc.

Stackebrandt, E. \& Goebel, B. M. (1994). Taxonomic note: a place for DNA-DNA reassociation and $16 \mathrm{~S}$ rRNA sequence analysis in the present species definition in bacteriology. Int J Syst Bacteriol 44, 846-849.

Wayne, L. G., Brenner, D. J., Colwell, R. R., Grimont, P. A. D., Kandler, O., Krichevsky, M. I., Moore, L. H., Moore, W. E. C., Murray, R. G. E. \& other authors (1987). International Committee on Systematic Bacteriology. Report of the ad hoc committee on reconciliation of approaches to bacterial systematics. Int $J$ Syst Bacteriol 37, 463-464.

Wu, C., Lu, X., Qin, M., Wang, Y. \& Ruan, J. (1989). Analysis of menaquinone compound in microbial cells by HPLC. Microbiology [English translation of Microbiology (Beijing)] 16, 176-178.

Yoon, J.-H., Lee, K.-C., Weiss, N., Kho, Y. H., Kang, K. H. \& Park, Y.-H. (2001). Sporosarcina aquimarina sp. nov., a bacterium isolated from seawater in Korea, and transfer of Bacillus globisporus (Larkin and Stokes 1967), Bacillus psychrophilus (Nakamura 1984) and Bacillus pasteurii (Chester 1898) to the genus Sporosarcina as Sporosarcina globispora comb. nov., Sporosarcina psychrophila comb. nov. and Sporosarcina pasteurii comb. nov., and emended description of the genus Sporosarcina. Int J Syst Evol Microbiol 51, 1079-1086.

Zhang, D.-C., Wang, H.-X., Cui, H.-L., Yang, Y., Liu, H.-C., Dong, X.-Z. \& Zhou, P.-J. (2007). Cryobacterium psychrotolerans sp. nov., a novel psychrotolerant bacterium isolated from the China No. 1 glacier. Int $J$ Syst Evol Microbiol 57, 866-869. 